\title{
Testing Metaknowledge of Phonological Components among English Freshman Students at Taif University
}

\author{
Prof Hassan El-Banna M Gaballa \\ Linguistics Professor \& Research Consultant Faculty of Arts Taif University Kingdom of Saudi Arabia \\ Testing Metaknowledge of Phonological Components among English Freshman Students at Taif University
}

\begin{abstract}
This study examined whether differences in phonological awareness were related to differences in speech comprehensibility. Seventeen of the newcomers to the Department of English at Taif University (TU) who learned English as a foreign language (EFL) in academic settings completed a total of seventeen tests of phonological awareness: fourteen of these measured their explicit knowledge of English phonological structures, and three tests of phonological short term memory. The same participants were also asked to read aloud a passage and to narrate picture stories. These tasks were used by five native speakers of English to rate $T U$ freshman EFL learners' comprehensibility on a nine-point scale. There was a strong positive correlation between composite phonological awareness scores and rated comprehensibility and between composite phonological awareness scores and phonological short term memory. The correlation between rated comprehensibility and phonological short term memory was not significant. A simple linear regression analysis showed that approximately 19\% of the variance in rated comprehensibility scores was accounted for by composite phonological awareness scores. The study offers support to the view that phonological awareness is related to differences in speech comprehensibility and the results suggest that form-focused instruction in phonology may contribute to the comprehensibility of TU freshman EFL learners.
\end{abstract}

Keywords: metaphonology, intelligibility, speech comprehensibility, focus on form, pronunciation, phonological awareness

\section{Introduction}

The study of metaknowledge of phonology (e.g., Jiménez \& Ortiz 2000) is a recent interest that draws attention of researchers in language literacy (Richards, Platt \& Platt 1992 \& Kaminski \& Good 1998); reading and reading disabilities (Eldredge 2004, Bravo-Valdivieso 1995 \& Campbell 2004); linguistic phonology (Durgunoglu et al.1993 \& Carrillo 1994 \& Abadzi et al. 2005); testing technology (Kaminski \& Good 1996 \& Kaminski et al. 2008), contemporary curriculum-design (Good \& Jefferson 1998 \& Hasbrouck \& Tindal 1992); second language acquisition (Davidson \& Strucker 2002, Stanovich 1986 \& Holt 1995), and language instruction (Kenworthy $1987 \&$ Jones $1996 \&$ Marston \& Magnusson 1988). Lyon (2002) has stated that reading deficits in many learners can be prevented if diagnosed early and a research based intervention is implemented. Jager-Adams (1997) has argued that the second best predictor of early reading achievement is an awareness of the phonemes in a spoken word. With this theoretical background, our appreciation of the practical and multidimensional facets of the issue, and our understanding of the barrenness of Arabic research of similar studies, the project seems justified. The paper tests the concept of metaknowledge of English sounds among TU English-majors-to-be. Its components are: Introduction, Literature Review; Project Motivation and Purpose; Study Design, Test Outline; and Method (Experiment Details).

\section{Literature Review}

Researchers, e.g., Ashmore et al., (2003) and Heilman (2002) have found that sound metaknowledge is the one area of instruction that has been missing, or that may have been inadequately addressed with early language learners, especially those struggling in the acquisition of another language. Our initial review of the available literature proves there an absence of metaknowledge teaching in the material on second language teaching methodology. In the meantime, there is a similar absence of research on the effect of metaknowledge language instruction. The Arab research arena in education and psychology, above all, is nearly empty of such attempts. Types of metaknowledge of phonological components are accessible from the literature on: phonemic structure (Bishop \& Bishop 1996), rhyme structure and manipulation (Bradley \& Bryant 1985), syllable formation rules (Liberman et al.1974), word formation (Bear et al. 2008), sentence recognition (Davidson \& Strucker 2002), and structuring metaknowledge raising practices (Denton et al. 2000 \& Hempenstall 2007). Moreover, the idea of developmental hierarchy for the emergence of metaknowledge of phonological skills were a major concern in designing our test. 
As with development in any area, variations in the acquisition of skills will be seen with different learners. However, the consistency with which researchers have identified skills emerging at different age levels provided a principal guideline for the project:

Knowing that words can rhyme - then production of rhymes,

Knowing that sentences are made up of words,

Knowing that words can be broken down into syllables - then identification of syllables,

Knowing that words begin with the same sound - then identification of the beginning sound of words,

Knowing that words end with the same sound - then identification of the final sound of words,

Manipulation and/or deletion of the initial or final sound of words,

Knowing that words can have the same medial sound - then identification of the medial sound,

Knowing that words can be broken down into individual phonemes,

Ability to blend sounds to make words, and

Ability to segment words into constituent sounds.

(Sources with relevant information include Hempenstall 2002; Adams 1990; Ball 1993; Catts \& Vartiainen 1993; Warrick, Rubin \& Rowe-Walsh 1993)

\section{STUDY MOTIVATION \& PURPOSE}

Because the present study examines phonological awareness in the absence of an experimental treatment, i.e. instruction, it can be seen as tapping into elements usually considered to be part of aptitude, especially pattern recognition and processing speed (considered to reflect abilities involved in Schmidt and Frota's (1986) idea of 'noticing the gap'), in addition to 'phonological working memory capacity' and 'phonological working memory speed' (Robinson 2005:51-56). Although Robinson indicates support for the idea that success in classroom learning correlates with measures of aptitude, there is little evidence that aptitude tests, i.e., ones that heavily focus on phonological awareness and pattern recognition, correlate with speech comprehensibility, although Robinson also reports on studies in which ability to learn from recasts appears to be related to phonetic sensitivity, suggesting that aptitude may play a role in speech comprehensibility.

The study also serves a number of closely-related theoretical and practical goals:

1) One of the learner-oriented objectives is to find out whether newcomers in the Department of Foreign Languages (mainly English-majors-to-be) have this type of metaknowledge which enables them to be successful English language learners.

2) One of the instructor-oriented purposes is to help TU instructors better understand how sound metaknowledge links oral language with emerging reading and writing skills.

3) Another instructor-oriented goal is to provide teachers with the type of metaknowledge that facilitates designing activities and materials which can be used to teach sound perception skills.

4) On a more abstract level, the project serves as a framework to show the relationship and sequence of phonological awareness to the mental processes of learning to read and write.

5) The researchers plan to include a sample of phonological metaknowledge activities to be used in daily classroom routine; this procedure should be integral to any language arts program.

6) Helping TU learners become informed of the sounds heard in the speech stream can be accomplished in many ways. Once instructors have the metaknowledge of what phonology encompasses, they will find ways of bringing this insight to their students.

\section{STUDY DESIGN}

This study was designed to determine if phonological awareness is related to speech comprehensibility in a group of TU learners. Specifically, the researchers are examining whether subjects with higher scores on a battery of tasks designed to measure phonological awareness also were rated as being more comprehensible. A strong positive correlation between phonological awareness and comprehensibility would appear to support Schmidt's (1990 \& 1995) noticing hypothesis. A TU learner with superior phonological awareness presumably notices the 'gap' between her production of a word and what the word actually requires, eventually leading to more comprehensible pronunciation. Indeed, an assumption of much language teaching, including the teaching of pronunciation, is that explicit knowledge of the language system is helpful, and perhaps even necessary. On the other hand, a weak or negative correlation between the two variables would suggest that phonological awareness does not significantly contribute to comprehensibility. In addition to phonological awareness, a second variable, which may be important, is phonological short term memory. Phonological memory is the ability to recall the sequences of phonemes in words and non-words. Obviously, all new words in both L1 and L2 begin as non-words until they are stored in long term memory with their meanings. Gathercole and Baddeley (1990) suggested that a non-word repetition task is a purer measure of phonological short term memory because it is less influenced by vocabulary stored in long term memory. 
Costanza et al. (1991) reported that phonological short term memory plays a significant role in foreign language vocabulary acquisition. The role of phonological short term memory in the development of phonological awareness and intelligible L2 pronunciation is not known. In the present study, two non-word repetition tasks were used to measure phonological short term memory of TU participants. We also explore the connection between phonological short term memory, phonological awareness and comprehensibility to examine whether phonological short term memory may play a role in articulatory mastery.

Moreover, the study depends upon constructing a metalinguistic test that integrates its main grounds from:

1) Exploring the phenomenon of metalanguage in early language learners to see if it can predict future performance.

2) Investigating:

Listening: the ability to attend to and distinguish both environmental and speech sounds from one another, i.e., by means of alertness (including location), sequencing, discrimination, figure-ground, memory (sound pattern concepts) and sound-symbol.

Rhyme: the correspondence of ending sounds of words or lines of verse. Rhyming is the ability to identify words that have identical final sound segments: exposure, judgment, (identify same or different), production (produce word with the same final sounds).

Word Grasp: the knowledge that sentences consist of words and that these words can be manipulated: pointing (words on page--notice spaces) and counting (number of words in sentence or phrase).

Syllable Discernment: the ability to hear parts or segments of phonemes that comprise the rhythm of the word: counting, segmenting, blending and deletion.

Phonemic Awareness: the ability to attend to, identify, and manipulate the sounds that are representative of graphemes in the English language. exposure to alliteration in text, initial sound identification/comparison, sound/symbol correspondence, final sound identification, phoneme counting (with and without visual aids), phoneme segmentation, phoneme blending (synthesis),phoneme deletion, and phoneme substitution.

\section{TEST OUTLINE}

In its potential four-part scheme, the test expands the following fundamental titles:

1) Phonics items to demonstrate the abstract process that stresses associating letters, i.e., visual symbols, with auditory sounds and may be illustrated to students in various contexts, mainly in isolation and at the beginning and ending of words.

2) Items of phonemic perception which approaches sound-symbol association from the opposite direction: students explore speech sounds by hearing, feeling and seeing their characteristics and comparing and contrasting their properties. The auditory element of the speech sound is connected to the more basic oralmotor activity by which the sound is produced;

3) Items that demonstrate their alertness, discrimination and perception, i.e., show their sense of sound intensity (understand the concept of loud/soft with respect to sound).

4) Items that reveal sound/word identification and may come from familiar nursery rhymes, short stories or familiar stories and poems already used in class;

5) Items that emphasize manipulation of words in sentences;

6) Items to highlight compound word segmentation, compound word deletion, syllable search and syllable categories; and,

7) Items that designate syllable addition, syllables with manipulatives, syllable identification, substitution of syllables and rotating syllables in compound words.

Finally, these are some limitations of metaknowledge of sound components in L2 contexts:

1) There is not an established knowledge base for teaching of metaknowledge in L2 contexts.

2) Metaknowledge instruction needs words for drawing generalizations.

3) Sound metaknowledge instructions involve pronunciation discrimination which some English-majors-to-be are still struggling with the sounds of their L2.

4) In TU, newcomers to English do not start to read English story books independently until quite late.

5) So far, language instruction in TU has been entrusted with too many objectives: pronunciation, vocabulary, spelling, etc. The purpose of a metaknowledge course is still not clear enough to many instructors.

\section{Participants}

\section{Method}

Seventeen TU freshman EFL learners completed a series of tasks that were designed to tap a range of phonological awareness skills (described in the 'Tasks' section). There were seven males and ten females in the group with a mean age of 20 years (range: 18-21). On average, they had studied English in a classroom for 
seven years (range: 6-8). All participants were college freshman students who scored a minimum of 470 on a local TOEFL (Test of English as a Foreign Language).

\section{Tasks}

There is no single standard set of tasks that measures phonological awareness. Typically, six types of skills are included in the domain of phonological awareness. Tasks used in this study to tap each of the six skill areas are described below. Fourteen separate tasks were used to evaluate phonological awareness.

1) Phonological blending is the ability to blend phonemes into syllables and syllables into words. A phonemeblending task in which the participants heard a sequence of isolated sounds with a short pause between them, e.g., $[\mathrm{k} æ \mathrm{t}]$ was used to measure the phoneme blending ability of participants. The participants responded by typing a word that they thought consisted of the sequence of sounds they heard. In order to be counted as correct, the spelling had to be correct, e.g., [bæk] required the response, back).

2) Phonological manipulation is the ability to add, delete, substitute, or rearrange phonemes or groups of phonemes within a word or a phrase. Three tasks were used to measure this skill area in the present study:

a) Initial consonant deletion. Participants were presented with a picture with its label written next to it. All words began with a consonant. They were asked to pronounce the word without the first consonant. Without the first consonant, all words changed to non-words(e.g. frog pronounced as [rog]).

b) Final consonant deletion. This was similar to the initial consonant deletion task described above, except that the participants pronounced the word without the final consonant.

c) Spoonerisms. The task was to exchange the initial sounds of words in two-word phrases, e.g., white fish and no tails, so that it would result in phrases with two different English words (fight wish and toe nails). The transformed phrases were not required to be meaningful as long as they consisted of real English words.

3) Phonological segmentation is the ability to decompose a word into phonemes and syllables. Two tasks, i.e., number of sounds in words and number of syllables in words, were used to test this ability.

a) In the first task, participants were presented with written single-syllable words one at a time and were asked to sound them out before entering the number of sounds present in each word.

(b) In the second task, the participants sounded out one- to four-syllable words one at a time before entering the number of syllables for each word.

4) Phonological sequencing ability allows a learner to identify the position of a specified phoneme or a sequence of phonemes within a word.

a) In the phoneme position identification task, the participant heard a word and, following a brief pause, a vowel or consonant produced in isolation. The participant was then to orally identify the sound that came after the reference sound. The responses were audio-recorded.

b) In the cluster identification task, the participant typed the word-initial or word-final consonant cluster upon hearing each word spoken. The words had either word-initial or word-final clusters but not both.

5) Rhyming and alliteration abilities include identification of rhyming and alliterating words as well as the ability to produce rhyming and alliterating words.

a) Identification of rhyme and identification of alliteration. Participants were presented with a set of three words on the computer screen, two of which rhymed (in the rhyming task) or alliterated (in the alliteration task). The participants checked off the two words that they thought rhymed or alliterated.

b) Rhyming fluency and alliteration fluency. The participants were given common single-syllable words, one for rhyming and one for alliteration separately, and asked to produce as many rhyming or alliterating words respectively as they could within 30 seconds. Responses were audio-recorded.

6) Non-word reading. Non-words are sequences of phonemes that conform to the phonotactic constraints of the language but without any semantic content. Reading a non-word would require converting text into a sequence of sounds and syllables and then applying a prosodic structure to the sequence before pronouncing it. The participants were presented with ten written non-words, one at a time and were asked to read them. Responses were audio-recorded and evaluated for two elements, each of which was scored separately:

a) the correct number of syllables, and

b) the correct placement of the main stress relative to how a native speaker of English (the second author) with extensive background in Linguistics and English as Second Language pronounced these words. Some of the non-words used on this task as well as the other two tasks described below were taken from Carter et al. (2002) and Gathercole et al. (1994).

\section{Phonological Short Term Memory Tasks}

(1) Picture-non-word association.

The participants were presented with a set of ten-line drawings for which English had no words. Each picture had a nonword label underneath it and the participants heard the spoken form of the non-word twice. After they 
had heard the labels for all the ten pictures, the pictures were rearranged in a pseudorandom order on the screen and the labels were shown at the bottom of the screen in pseudorandom order. The participants were asked to match the labels with the pictures by typing the labels in the space provided below the pictures.

(2) Non-word repetition.

The participants immediately repeated a non-word they heard. Their responses were audio-recorded and were evaluated for two separate areas:

a) the correct number of syllables, and

b) the correct placement of primary stress relative to the spoken testword.

\section{Procedures}

A computer program was written in Visual Basic 5, which presented each of the tasks on a computer screen. The program recorded and tallied correct and incorrect responses for those tasks that required a typed response. The program also audio-recorded responses for tasks that required an oral response. A TU teaching assistant listened to the audio recordings and tallied the correct and incorrect responses. For each of the tasks, there was a practice period preceding the presentation of test items. During the practice trials, prompts and explanations were freely given to maximize correct responses. This was to ensure that participants understood the requirements of the task. However, errors were not explicitly corrected. During the test, participants followed standard written instructions presented on the screen without any additional prompts, explanations, or feedback. The screen layout and written instructions on tests were identical to those on the practice trials. Practice trials consisted of five items and the test tasks typically included ten items. The exceptions were rhyming and alliteration fluency tasks where participants produced as many rhyming and alliterating words as they could within thirty seconds. No practice items were used as test items.

\section{Comprehensibility Ratings}

Each TU participant in the study read one of the several short passages and narrated a sequence of pictures that depicted a story. Each text was one hundred-and-twenty words long. The number of words that fell within the two thousand most frequent words in English ranged from 86 to $91 \%$, as measured by the Compleat Lexical Tutor (http://132.208.224.131/). The participants were allowed to read the passages silently just prior to reading them aloud and to examine the pictures silently for a short time before describing them. From each EFL learner's reading and narration, three read sentences and three picture description sentences were extracted. The first and the last sentences read and spoken by a participant were excluded from selection to allow for warm-up and cool-down. In addition, incomplete sentences, sentences with false starts and/or phrase repetitions and very short sentences (those with less than four words) were excluded. A computer program, written in Visual Basic 5, presented the sentences to ten raters individually through headphones. The raters listened to the read and spoken sentences alternately; the fifty-one $(17 \times 3)$ read and fifty-one spoken sentences were, however, presented in a pseudorandom order to each rater, so that no two raters heard the fifty-one read and fifty-one spoken sentences in the same order.

The raters judged the comprehensibility of how each sentence was said on a 9-point Likert scale $(1=$ extremely difficult to understand; $9=$ extremely easy to understand). The program recorded the responses and saved them in a text file. At the start of the listening session, each rater listened to the same two read and two spoken sentences, one at a time. The raters were told that the first sentence in each group was representative of sentences that were easy to understand and the second, an example of a sentence that was hard to understand. This was done to inform raters of the range of performance they were likely to encounter so that they would make use of the entire scale -1 through to 9 - when rating sentences.

\begin{tabular}{|l|l|l|l|l|l|l|l|}
\hline Sentences & Mean rating & $\begin{array}{l}\text { Mean } \\
\text { minimum } \\
\text { rating }\end{array}$ & $\begin{array}{l}\text { Mean } \\
\text { maximum } \\
\text { rating }\end{array}$ & $\begin{array}{l}\text { Cronbach's } \\
\text { alpha }\end{array}$ & $\begin{array}{l}\text { Mean } \\
\text { correlation }\end{array}$ & $\begin{array}{l}\text { ICC (single } \\
\text { measures) }\end{array}$ & $\begin{array}{l}\text { ICC } \\
\text { (average } \\
\text { measures) }\end{array}$ \\
\hline Reading 1 & 6.09 & 4.82 & 7.29 & 0.950 & 0.627 & 0.614 \\
\hline Reading 2 & 5.87 & 4.71 & 6.88 & 0.953 & 0.642 & 0.627 \\
\hline Reading 3 & 5.47 & 4.29 & 6.82 & 0.935 & 0.581 & 0.546 & 0.953 \\
\hline Speaking 1 & 5.33 & 4.12 & 6.24 & 0.946 & 0.621 & 0.595 \\
\hline Speaking 2 & 5.08 & 3.94 & 5.94 & 0.905 & 0.447 & 0.443 \\
\hline Speaking 3 & 4.77 & 3.65 & 5.65 & 0.845 & 0.312 & 0.312 \\
\hline
\end{tabular}

Table 1 Inter-rater reliability measures for 12 raters for three sentences each read and spoken by seventeen TU participants. (ICC: intraclass correlation coefficient) 
Table 1 presents statistics concerning the inter-rater reliability of 12 raters. The mean ratings as well as mean minimum and mean maximum ratings, for the most part, occupy the middle of the rating scale, indicating that raters generally avoided giving extremely low or extremely high ratings to sentences they listened to. The EFL participants in this group were all college students who had to meet certain minimum English proficiency standards to be admitted to their degree programs. On the other hand, no participant had native-like proficiency in spoken English. This probably explains why there were few very high and very low ratings.

To measure inter-rater reliability, in addition to the various mean ratings, intraclass correlation coefficients (ICC) for consistency were computed using the two-way mixed effects model where rater effects were random and rating effects were fixed. The Cronbach's alpha values reported in Table 1 are very high, indicating that there was a high degree of consistency among raters. The samples that were highly rated by one rater also received high ratings by other raters and vice versa. However, the ICC (single measures) values are lower, indicating there was less absolute agreement among raters for individual samples. Overall, the consistency among raters is satisfactory. This is in line with the results reported by Derwing and Munro (1997), Derwing and Rossiter, M. (2003), and Munro and Derwing (1995), who have also reported that untrained listeners produce highly reliable ratings.

\section{Results}

\begin{tabular}{|c|c|c|c|c|}
\hline Tasks. & Mean & St. Dev & $\operatorname{Max}$ & Min \\
\hline 1. Alliteration & 0.776 & 0.164 & 1.00 & 0.40 \\
\hline 2. Alliteration fluency & 0.641 & 0.184 & 0.90 & 0.20 \\
\hline 3. Rhyming & 0.876 & 0.135 & 1.00 & 0.50 \\
\hline 4. Rhyme fluency & 0.331 & 0.193 & 0.60 & 0.10 \\
\hline 5. Spoonerisms & 0.518 & 0.194 & 0.90 & 0.30 \\
\hline 6. Number of sounds in words & 0.724 & 0.211 & 1.00 & 0.20 \\
\hline 7. Number of syllables in words & 0.618 & 0.198 & 1.00 & 0.40 \\
\hline 8. Initial consonant deletion & 0.906 & 0.144 & 1.00 & 0.60 \\
\hline 9. Final consonant deletion & 0.894 & 0.100 & 1.00 & 0.70 \\
\hline 10. Phoneme blending & 0.547 & 0.194 & 0.90 & 0.20 \\
\hline 11. Phoneme position identification & 0.741 & 0.191 & 1.00 & 0.40 \\
\hline 12. Cluster identification & 0.812 & 0.196 & 1.00 & 0.40 \\
\hline 13. Non-word reading (number of syllables) & 0.900 & 0.079 & 1.00 & 0.70 \\
\hline 14. Non-word reading (stress placement) & 0.788 & 0.136 & 1.00 & 0.60 \\
\hline 15. Picture-non-word association & 0.718 & 0.253 & 1.00 & 0.30 \\
\hline 16. Non-word repetition (number of syllables) & 0.882 & 0.221 & 1.00 & 0.10 \\
\hline 17. Non-word repetition (stress placement). & 0.876 & 0231 & 1.00 & 0.10 \\
\hline
\end{tabular}

Table 2 Mean, maximum and minimum proportions and standard deviations for 17 measurements obtained from EFL participants

Table 2 presents summary data for 17 measures obtained in the study. Mean proportions reported in Table 2 were computed by dividing the number of correct responses by total items in each task for each participant and then computing the mean of these proportions. For alliteration and rhyme fluency tasks, which did not have a set number of items, the denominator was 10 . Rhyme fluency data for four participants, and initial and final consonant deletion data for one participant each were unavailable due to technical problems with the computer. The performance of the group was poorest in rhyme fluency. This might be, in part, due to the loss of data for four participants. Except for rhyme fluency, participants as a group tended to score in the 50 to $90 \%$ range in other tasks. Performance of individual participants, however, varied considerably on different tasks with some participants scoring as low as $20 \%$ on some phonological awareness tasks, while at least one participant scoring $100 \%$ on all but four tasks (alliteration fluency, rhyme fluency, spoonerisms, and phoneme blending). Clearly, most of the participants possessed a significant amount of phonological awareness. The performance of the group on phonological memory tasks (tasks15-17 in Table 3) followed a similar pattern.

\begin{tabular}{|c|c|c|c|c|c|c|}
\hline \multirow{3}{*}{$\begin{array}{l}\text { Participants } \\
1\end{array}$} & \multicolumn{2}{|c|}{$\begin{array}{l}\text { Phonological awareness } \\
\text { tasks (1-14) }\end{array}$} & \multicolumn{2}{|c|}{$\begin{array}{l}\text { Phonological short term } \\
\text { memory tasks (15-17) }\end{array}$} & \multicolumn{2}{|c|}{$\begin{array}{l}\text { Intelligibility ratings (on a } \\
\text { scale } 1 \text { to 9) }\end{array}$} \\
\hline & Mean & SD & Mean & SD & Mean & $\mathrm{SD}$ \\
\hline & 0.68 & 0.27 & 0.93 & 0.12 & 6.56 & 1.93 \\
\hline 2 & 0.69 & 0.21 & 0.40 & 0.52 & 4.07 & 1.83 \\
\hline 3 & 0.71 & 0.24 & 0.83 & 0.29 & 6.14 & 1.75 \\
\hline 4 & 0.62 & 0.15 & 0.63 & 0.29 & 4.92 & 1.94 \\
\hline 5 & 0.73 & 0.24 & 0.57 & 0.15 & 5.46 & 1.87 \\
\hline 6 & 0.66 & 0.24 & 0.80 & 0.00 & 5.19 & 2.24 \\
\hline 7 & 0.82 & 0.15 & 1.00 & 0.00 & 3.63 & 2.13 \\
\hline 8 & 0.72 & 0.23 & 0.77 & 0.32 & 6.53 & 1.81 \\
\hline
\end{tabular}




\begin{tabular}{|c|c|c|c|c|c|c|}
\hline 9 & 0.62 & 0.23 & 0.93 & 0.06 & 3.29 & 1.92 \\
\hline 10 & 0.68 & 0.30 & 0.87 & 0.15 & 3.79 & 1.72 \\
\hline 11 & 0.78 & 0.19 & 1.00 & 0.00 & 4.64 & 1.75 \\
\hline 12 & 0.80 & 0.23 & 1.00 & 0.00 & 6.64 & 1.66 \\
\hline 13 & 0.71 & 0.28 & 0.80 & 0.10 & 7.19 & 1.58 \\
\hline 14 & 0.70 & 0.23 & 0.83 & 0.29 & 5.24 & 2.05 \\
\hline 15 & 0.79 & 0.20 & 0.93 & 0.12 & 6.51 & 1.60 \\
\hline 16 & 0.90 & 0.12 & 1.00 & 0.00 & 7.65 & 1.83 \\
\hline 17 & 0.64 & 0.23 & 0.73 & 0.29 & 4.96 & 1.90 \\
\hline
\end{tabular}

Table 3 Mean proportions and standard deviations for phonological awareness and phonological short-term memory tasks and intelligibility ratings for 17 EFL participants

Table 3 presents composite means for phonological awareness and phonological short term memory tasks for each participant along with his/her rated comprehensibility scores. Composite means are in the upper half of the range for both phonological awareness and phonological memory tasks (except for one participant who scored 0.4 on phonological memory). In contrast, comprehensibility ratings generally fall in the low to middle portions of the range with only two participants scoring above 7 on the 9-point scale. Classroom learning of L2 appears to ensure a certain level of phonological awareness. Generally, those who scored in the upper ranges of phonological awareness and tasks were also rated higher in comprehensibility. In contrast, no clear pattern of association appears to exist between comprehensibility ratings and phonological short term-memory.

Table 4 shows a matrix of correlation coefficients for the 17 tasks used in this study. The Pearson's correlation coefficient between mean rated comprehensibility scores and mean composite phonological awareness scores was significant $(\mathrm{r}$ [17] $=0.491, \mathrm{p}<0.05)$ indicating that the two measures are related. Pearson's $\mathrm{r}$ in the neighborhood of 0.5 is considered large when measuring the strength of association between two separate but related variables (Cohen 1996). In fact, according to Cohen, correlations much larger than 0.5 are 'measuring the same thing' rather than two different variables. A simple linear regression analysis with composite phonological awareness scores as the independent variable and the rated comprehensibility scores as the dependent variable showed that, conservatively, $19 \%$ of the variance in rated comprehensibility scores was accounted for by phonological awareness scores $(\mathrm{R} 2=0.241$; adjusted $\mathrm{R} 2=0.190)$. In the present study, phonological awareness was a factor in comprehensibility, although it is clearly not the whole story.

The correlation between phonological short term memory and speech comprehensibility was non-significant ( $\mathrm{r}$ $[17]=0.199, p>0.05)$. The phonological short term memory scores are clustered at the top of the range, which suggests the presence of a ceiling effect. The non-significant correlation between speech comprehensibility and phonological short term memory may, in part, be the result of this ceiling effect. Phonological short term memory, however, was highly correlated with some aspects of phonological awareness $(\mathrm{r}[17]=0.502, \mathrm{p}<0.05)$. Two phonological awareness tasks - alliteration fluency $(\mathrm{r}[17]=0.628, \mathrm{p}<0.01)$ and initial sound deletion $(\mathrm{r}$ $[17]=0.827, \mathrm{p}<0.01)-$ correlated highly with phonological short term memory. The very high correlations suggest that these two tasks and phonological short term memory probably tap the same pool of cognitive resources. Other phonological awareness tasks were non-significantly correlated with phonological short term memory. The three purported phonological short term memory tests do not appear to measure the same underlying construct, given that Cronbach's alpha coefficient was only 0.53 for the three tasks. Nunnaly (1978) and George and Mallory (2003) have stated that an alpha value of 0.7 or higher is an adequate measure of internal reliability for tests.

Among the phonological awareness tasks, rhyme and alliteration identification tasks ( $\mathrm{r}[17]=0.511, \mathrm{p}$ $<0.05$ ), spoonerisms and the number of syllables tasks $(\mathrm{r}[17]=0.577, \mathrm{p}<0.05)$, rhyme identification and cluster identification tasks $(\mathrm{r}[17]=0.483, \mathrm{p}<0.05)$, the number of sounds and cluster identification tasks $(\mathrm{r}$ $[17]=0.506, \mathrm{p}<0.05)$, and cluster identification and non-word reading with correct number of syllables tasks $(\mathrm{r}$ $[17]=0.563, \mathrm{p}<0.05)$ were significantly correlated. The number of syllables task correlated highly with sound blending $(r[17]=0.499, p<0.05)$, sound position identification $(r[17]=0.544, p<0.05)$ and non-word reading with correct stress placement $(\mathrm{r}[17]=0.565, \mathrm{p}<0.05)$. However, correlations are not perfect or even near perfect, indicating that each task also required unique knowledge not shared with other tasks. Other correlations among the phonological awareness tasks did not reach statistical significance. Overall, however, the numerous significant correlations suggest that the different phonological awareness tasks share a common knowledge base. Cronbach's alpha was 0.73 for the 14 phonological awareness tasks, indicating an adequate level of internal reliability for these tests. 


\begin{tabular}{|c|c|c|c|c|c|c|c|c|c|c|c|c|c|c|c|c|c|}
\hline & 1 & 2 & 3 & 4 & 5 & 6 & 7 & 8 & 9 & 10 & 11 & 12 & 13 & 14 & 15 & 16 & 17 \\
\hline 1 & & $\begin{array}{l}0.1 \\
6\end{array}$ & $\begin{array}{l}0.1 \\
5 *\end{array}$ & $\begin{array}{l}- \\
0.3 \\
5 \\
\end{array}$ & $\begin{array}{l}0.5 \\
6^{*}\end{array}$ & $\begin{array}{l}0.5 \\
1 *\end{array}$ & $\begin{array}{l}0.84 \\
* *\end{array}$ & 0,38 & $\begin{array}{l}- \\
0.2 \\
3\end{array}$ & $\begin{array}{l}0.5 \\
3^{*}\end{array}$ & $\begin{array}{l}0.62 \\
* *\end{array}$ & $\begin{array}{l}0.5 \\
7 *\end{array}$ & $\begin{array}{l}0.50 \\
*\end{array}$ & $\begin{array}{l}0.59 \\
*\end{array}$ & 0.26 & 0.42 & 0.40 \\
\hline 2 & $\begin{array}{l}0.1 \\
6\end{array}$ & & $\begin{array}{l}0.1 \\
9\end{array}$ & $\begin{array}{l}0.1 \\
0\end{array}$ & $\begin{array}{l}0.0 \\
8\end{array}$ & $\begin{array}{l}- \\
0.1 \\
1\end{array}$ & 0.32 & 0.64 & $\begin{array}{l}- \\
0.0 \\
2\end{array}$ & $\begin{array}{l}- \\
0.1 \\
1\end{array}$ & 0.16 & $\begin{array}{l}0.2 \\
5\end{array}$ & 0.09 & 0.47 & $\begin{array}{l}0.63 \\
* *\end{array}$ & 0.40 & 0.14 \\
\hline 3 & $\begin{array}{l}0.5 \\
1 *\end{array}$ & $\begin{array}{l}0.1 \\
9\end{array}$ & & $\begin{array}{l}- \\
0.3 \\
2 \\
\end{array}$ & $\begin{array}{l}0.2 \\
8\end{array}$ & $\begin{array}{l}- \\
0.0 \\
2 \\
\end{array}$ & 0.13 & 0.29 & $\begin{array}{l}- \\
0.1 \\
4 \\
\end{array}$ & $\begin{array}{l}0.0 \\
7\end{array}$ & $\begin{array}{l}- \\
0.06\end{array}$ & $\begin{array}{l}0.4 \\
8 *\end{array}$ & 0.29 & 0.12 & 0.34 & 0.43 & 0.13 \\
\hline 4 & $\begin{array}{l}- \\
0.3 \\
5 \\
\end{array}$ & $\begin{array}{l}0.1 \\
0\end{array}$ & $\begin{array}{l}- \\
0.3 \\
2 \\
\end{array}$ & & $\begin{array}{l}- \\
0.1 \\
9 \\
\end{array}$ & $\begin{array}{l}0.3 \\
8\end{array}$ & 0.21 & 0.35 & $\begin{array}{l}0.0 \\
0\end{array}$ & $\begin{array}{l}0.4 \\
2\end{array}$ & 0.31 & $\begin{array}{l}0.0 \\
4\end{array}$ & 0.34 & 0.23 & 0.32 & 0.42 & 0.16 \\
\hline 5 & $\begin{array}{l}0.1 \\
1\end{array}$ & $\begin{array}{l}0.0 \\
8\end{array}$ & $\begin{array}{l}0.2 \\
8\end{array}$ & $\begin{array}{l}- \\
0.1 \\
9 \\
\end{array}$ & & $\begin{array}{l}0.4 \\
2\end{array}$ & $\begin{array}{l}0.58 \\
*\end{array}$ & $\begin{array}{l}- \\
0.01\end{array}$ & $\begin{array}{l}- \\
0.4 \\
1 \\
\end{array}$ & $\begin{array}{l}0.1 \\
9\end{array}$ & 0.15 & $\begin{array}{l}0.5 \\
2 *\end{array}$ & 0.20 & 0.13 & 0.20 & $\begin{array}{l}0.56 \\
*\end{array}$ & 0.02 \\
\hline 6 & $\begin{array}{l}- \\
0.0 \\
5 \\
\end{array}$ & $\begin{array}{l}- \\
0.1 \\
1\end{array}$ & $\begin{array}{l}- \\
0.0 \\
2 \\
\end{array}$ & $\begin{array}{l}0.3 \\
8\end{array}$ & $\begin{array}{l}0.4 \\
2\end{array}$ & & 0.47 & $\begin{array}{l}- \\
0.05\end{array}$ & $\begin{array}{l}- \\
0.0 \\
8\end{array}$ & $\begin{array}{l}0.0 \\
8\end{array}$ & 0.41 & $\begin{array}{l}0.5 \\
1 *\end{array}$ & 0.38 & 0.08 & -009 & $\begin{array}{l}0.51 \\
*\end{array}$ & 0.16 \\
\hline 7 & $\begin{array}{l}0.3 \\
4\end{array}$ & $\begin{array}{l}0.3 \\
2\end{array}$ & $\begin{array}{l}0.1 \\
3\end{array}$ & $\begin{array}{l}0.2 \\
1\end{array}$ & $\begin{array}{l}0.5 \\
8^{*}\end{array}$ & $\begin{array}{l}0.4 \\
7\end{array}$ & & 0.16 & $\begin{array}{l}- \\
0.3 \\
2\end{array}$ & $\begin{array}{l}0.5 \\
0 *\end{array}$ & $\begin{array}{l}0.54 \\
*\end{array}$ & $\begin{array}{l}0.4 \\
3\end{array}$ & 0.16 & $\begin{array}{l}0.57 \\
*\end{array}$ & 0.30 & $\begin{array}{l}0.84 \\
* *\end{array}$ & 0.24 \\
\hline 8 & $\begin{array}{l}0.2 \\
9\end{array}$ & $\begin{array}{l}0.4 \\
6\end{array}$ & $\begin{array}{l}0.2 \\
9\end{array}$ & $\begin{array}{l}0.3 \\
5\end{array}$ & $\begin{array}{l}- \\
0.0 \\
1\end{array}$ & $\begin{array}{l}0.0 \\
5\end{array}$ & 0.16 & & $\begin{array}{l}0.3 \\
4\end{array}$ & $\begin{array}{l}- \\
0.0 \\
8 \\
\end{array}$ & 0.30 & $\begin{array}{l}0.0 \\
9\end{array}$ & -0.11 & 0.14 & $\begin{array}{l}0.83 \\
* *\end{array}$ & 0.38 & 0.27 \\
\hline 9 & $\begin{array}{l}0.0 \\
3\end{array}$ & $\begin{array}{l}- \\
0.0 \\
2 \\
\end{array}$ & $\begin{array}{l}- \\
0.1 \\
4 \\
\end{array}$ & $\begin{array}{l}0.0 \\
0\end{array}$ & $\begin{array}{l}0.4 \\
1\end{array}$ & $\begin{array}{l}- \\
0.0 \\
8 \\
\end{array}$ & $\begin{array}{l}-32 \\
0.32\end{array}$ & 0.34 & & $\begin{array}{l}- \\
0.1 \\
2 \\
\end{array}$ & 0.19 & $\begin{array}{l}- \\
0.4 \\
6 \\
\end{array}$ & -0.43 & $\begin{array}{l}- \\
0.58 \\
* \\
\end{array}$ & 0.04 & -0.23 & 0.03 \\
\hline 10 & $\begin{array}{l}0.4 \\
5\end{array}$ & $\begin{array}{l}- \\
\\
0.1 \\
1\end{array}$ & $\begin{array}{l}0.0 \\
7\end{array}$ & $\begin{array}{l}0.4 \\
2\end{array}$ & $\begin{array}{l}0.1 \\
9\end{array}$ & $\begin{array}{l}0.0 \\
8\end{array}$ & $\begin{array}{l}0.50 \\
*\end{array}$ & $\begin{array}{l}- \\
0.08\end{array}$ & $\begin{array}{l}- \\
0.1 \\
2 \\
\end{array}$ & & 0.33 & $\begin{array}{l}- \\
0.1 \\
3 \\
\end{array}$ & 0.24 & 0.35 & 0.04 & 0.53 & 0.48 \\
\hline 11 & $\begin{array}{l}0.3 \\
3\end{array}$ & $\begin{array}{l}0.1 \\
6\end{array}$ & $\begin{array}{l}- \\
0.0 \\
6 \\
\end{array}$ & $\begin{array}{l}0.3 \\
1\end{array}$ & $\begin{array}{l}0.1 \\
5\end{array}$ & $\begin{array}{l}0.4 \\
1\end{array}$ & $\begin{array}{l}0.54 \\
*\end{array}$ & 0.30 & $\begin{array}{l}0.1 \\
9\end{array}$ & $\begin{array}{l}0.3 \\
3\end{array}$ & & $\begin{array}{l}0.0 \\
4\end{array}$ & 0.17 & 0.36 & 0.30 & $\begin{array}{l}0.62 \\
* *\end{array}$ & $\begin{array}{l}0.62 \\
* *\end{array}$ \\
\hline 12 & $\begin{array}{l}0.0 \\
1\end{array}$ & $\begin{array}{l}0.2 \\
5\end{array}$ & $\begin{array}{l}0.4 \\
8\end{array}$ & $\begin{array}{l}0.0 \\
4\end{array}$ & $\begin{array}{l}0.5 \\
2\end{array}$ & $\begin{array}{l}0.5 \\
1\end{array}$ & 0.43 & 0.09 & $\begin{array}{l}- \\
0.4 \\
6 \\
\end{array}$ & $\begin{array}{l}- \\
0.1 \\
3 \\
\end{array}$ & 0.04 & & $\begin{array}{l}0.56 \\
*\end{array}$ & 0.31 & 0.09 & $\begin{array}{l}0.05 \\
7 * *\end{array}$ & -0.03 \\
\hline 13 & $\begin{array}{l}- \\
0.0 \\
5 \\
\end{array}$ & $\begin{array}{l}0.0 \\
9\end{array}$ & $\begin{array}{l}0.2 \\
9\end{array}$ & $\begin{array}{l}0.3 \\
4\end{array}$ & $\begin{array}{l}0.2 \\
0\end{array}$ & $\begin{array}{l}0.3 \\
8\end{array}$ & 0.16 & $\begin{array}{l}- \\
0.11\end{array}$ & $\begin{array}{l}- \\
0.4 \\
3 \\
\end{array}$ & $\begin{array}{l}0.2 \\
4\end{array}$ & 0.17 & $\begin{array}{l}0.5 \\
6^{*}\end{array}$ & & $\begin{array}{l}0.52 \\
*\end{array}$ & 0.11 & 0.50 & 0.35 \\
\hline 14 & $\begin{array}{l}0.1 \\
8\end{array}$ & $\begin{array}{l}0.5 \\
0\end{array}$ & $\begin{array}{l}0.1 \\
2\end{array}$ & $\begin{array}{l}0.2 \\
3\end{array}$ & $\begin{array}{l}0.1 \\
2\end{array}$ & $\begin{array}{l}0.0 \\
8\end{array}$ & 0.57 & 0.14 & $\begin{array}{l}- \\
0.5 \\
8^{*}\end{array}$ & $\begin{array}{l}0.3 \\
5\end{array}$ & 0.36 & $\begin{array}{l}0.3 \\
1\end{array}$ & $\begin{array}{l}0.52 \\
*\end{array}$ & & 0.33 & $\begin{array}{l}0.59 \\
*\end{array}$ & $\begin{array}{l}0.57 \\
*\end{array}$ \\
\hline 15 & $\begin{array}{l}0.2 \\
6\end{array}$ & $\begin{array}{l}0.6 \\
3\end{array}$ & $\begin{array}{l}0.3 \\
4\end{array}$ & $\begin{array}{l}0.3 \\
2\end{array}$ & $\begin{array}{l}0.2 \\
0\end{array}$ & $\begin{array}{l}- \\
0.0 \\
9 \\
\end{array}$ & 0.30 & $\begin{array}{l}0.83 \\
* *\end{array}$ & $\begin{array}{l}0.0 \\
4\end{array}$ & $\begin{array}{l}0.0 \\
4\end{array}$ & 0.30 & $\begin{array}{l}0.0 \\
9\end{array}$ & 0.11 & 0.33 & & 0.50 & 0.20 \\
\hline 16 & $\begin{array}{l}0.4 \\
2\end{array}$ & $\begin{array}{l}0.4 \\
0\end{array}$ & $\begin{array}{l}0.4 \\
3\end{array}$ & $\begin{array}{l}0.4 \\
2\end{array}$ & $\begin{array}{l}0.5 \\
6^{*}\end{array}$ & $\begin{array}{l}0.5 \\
1\end{array}$ & $\begin{array}{l}0.84 \\
* *\end{array}$ & 0.38 & $\begin{array}{l}- \\
0.2 \\
3\end{array}$ & $\begin{array}{l}0.5 \\
3\end{array}$ & $\begin{array}{l}0.62 \\
* *\end{array}$ & $\begin{array}{l}0.5 \\
7\end{array}$ & 0.50 & 0.59 & 0.50 & & 0.49 \\
\hline 17 & $\begin{array}{l}0.4 \\
0\end{array}$ & $\begin{array}{l}0.1 \\
4\end{array}$ & $\begin{array}{l}0.1 \\
3\end{array}$ & $\begin{array}{l}0.1 \\
6\end{array}$ & $\begin{array}{l}0.0 \\
2\end{array}$ & $\begin{array}{l}0.1 \\
6\end{array}$ & 0.24 & 0.27 & $\begin{array}{l}0.0 \\
3\end{array}$ & $\begin{array}{l}0.4 \\
8\end{array}$ & $\begin{array}{l}0.62 \\
* *\end{array}$ & $\begin{array}{l}- \\
0.0 \\
3\end{array}$ & 0.35 & 0.57 & 0.20 & 0.49 & \\
\hline
\end{tabular}

Table 4 Correlation matrix for phonological awareness tasks, phonological memory and rated intelligibility scores

1. Alliteration; 2. Alliteration fluency; 3. Rhyming; 4. Rhyme fluency; 5. Spoonerisms; 6. Number of sounds in words; 7. Number of syllables in words; 8 . Initial consonant deletion; 9. Final consonant deletion; 10. Phoneme blending; 11. Phoneme position identification; 12. Cluster identification; 13. Non-word reading(number of syllables); 14. Non-word reading (stress placement); 15. Phonological memory (picture-non-word association, non-word repetition [number of syllables], and non-word repetition [stress placement]) 16. Composite phonological awareness scores; 17. Rated intelligibility scores. $* \mathrm{p}<0.05 ; * * \mathrm{p}<0.01$

There was no significant correlation between the number of years English was studied and composite phonological awareness scores $(\mathrm{r}[17]=-0.092, \mathrm{p}>0.7)$ or between years English was studied and rated comprehensibility scores $(\mathrm{r}[17]=-0.147, \mathrm{p}>0.5)$. This is not surprising considering the quality and quantity of classroom instruction varies considerably as do individual learners' aptitude and effort. There were also no significant correlations between months living in an English-speaking country and phonological awareness(r $[17]=0.221, \mathrm{p}>0.3)$ and rated comprehensibility scores $(\mathrm{r}[17]=-0.240, \mathrm{p}>0.3)$. Generally, living in an L2 
environment has a positive effect on comprehensibility, especially in the initial months and years (Piske et al. 2001).

\section{Discussion \& Conclusion}

The results indicate that phonological awareness may be a factor in the comprehensibility of TU freshman EFL learners. Greater amounts of explicit knowledge of phonological patterns and rules, as measured by the phonological awareness tasks, may have facilitated greater speech comprehensibility. The findings provide some support for Schmidt's noticing hypothesis (1990; Schmidt \& Frota 1986), i.e., EFL learners with superior explicit knowledge of phonological structures and patterns of English were generally rated as more intelligible learners. However, given that phonological awareness accounted for only $19 \%$ of the variance in rated comprehensibility, it appears that 'noticing' phonological structures and patterns in L2 input is not the only aspect related to highly intelligible speech. Schmidt's contention that additional, beneficial learning can occur when L2 learners consciously analyze and understand language structures and patterns appears to find support in this study. Given the incomplete knowledge of the subjects' instructional backgrounds, we cannot be certain where the differences in phonological awareness developed.

The results of this study leave open an obvious question. It is not clear whether teaching phonological awareness will help L2 learners become more comprehensible. Most focus-on-form (FonF), or form-focused instruction, i.e., an approach to language instruction in which learners are made aware of the grammatical form of language features that they are already able to use communicatively, research indicates that pedagogical intervention that calls attention to formal properties of the L2 encourages greater levels of accuracy, that when pedagogical strategies are used to highlight formal properties of language, learners benefit and may learn the language at a faster rate than would otherwise be possible (Long \& Robinson 1998). Although most FonF research has examined syntactic and lexical form, there is no reason to believe that phonological form would not be amenable to the same kind of awareness-building strategies in the classroom (Doughty \&Williams 1998). Indeed, it is a basic assumption of most classrooms that explicit pedagogical interventions are helpful. What is not clear is whether traditional pronunciation teaching techniques are effective in promoting noticing. It is likely that pronunciation pedagogy is full of 'focus on forms' (Long \& Robinson 1998) practices, many of which may not be effective in producing greater comprehensibility.

It is not uncommon to find L2 learners who, after many years of exposure to the language, have reached a plateau that is well short of being sufficient to meet their comprehensibility needs. It is possible that a significant cause of this plateau is the hit-or-miss approach to phonological instruction that appears to be common throughout the world, at least in the teaching of English. Multiple studies have indicated that teachers simply do not teach pronunciation, partly because they do not feel that they know how (Burgess \& Spencer 2000; MacDonald 2003; Murphy 1997). It may be that the FonF approach that seems so promising in the teaching of other language forms has not been tried sufficiently with phonological awareness.

The findings do not support a strong version of Krashen's (1981, 1982 \& 1994) theory that explicit knowledge of language structures and rules are detrimental to L2 performance because they interfere with the implicitly acquired system of knowledge, which, according to Krashen, is the source of L2 competence. In the present study, TU freshman learners who had explicit phonological knowledge were not at a disadvantage. Instead, they appear to have benefited from that knowledge. If explicit and implicit forms of knowledge are indeed additive, then form-focused instruction in a milieu of meaningful exposure to language should accrue maximum benefit.

The present study, which is based on a correlational analysis, cannot be used to categorically conclude that greater phonological awareness causes greater comprehensibility. What it does suggest is that such awareness may be an important factor predicting whether an L2 learner is likely to be easier or more difficult to understand. A logical next step would be an experimental study to examine whether such awareness raising actually helps. Instructing L2 learners in phonological awareness and comparing pre- and post-instruction speech samples may answer more precisely whether comprehensibility can be improved through promotion of awareness. It is also an open question as to whether such awareness building requires a teacher at all. Instruction in most of the phonological awareness skill areas measured in this study can be presented through a computer interface.

\section{References}

[1]. Abadzi, H., L. Crouch, M. Echegaray, C. Pasco \& J. Sampe (2005). Monitoring basic skills acquisition through rapid learning assessments: A case study from Perú. Prospects, 35(2) 137-156.

[2]. Abouzeid, M (1996) Hyperlexia: A case study in the search for meaning. Journal of Reading Behavior, 27 (4) $585-603$.

[3]. Abouzeid, M., M. Invernizzi, D. Bear \& K. Ganske (2000) Approaching phonics through spelling. The California Reader, the literacy journal of the California State Literacy Association, 33 (4) 21-28.

[4]. Adams, M. J. (1990) Beginning to read: Thinking and learning about print. Cambridge, MA: MIT Press.

[5]. Anderson, R. C. (1992) Research foundations for wide reading. Paper commissioned by the World Bank. Urbana, IL: Center for the Study of Reading. 
[6]. Ashmore, R. A., M. Farrier, L. Paulson \& X. Chu (2003) The effects of phonemic awareness drills on phonological awareness and word reading performance in a later learned alphabetic script. Reading improvement, 40(1) 33-47.

[7]. Baker, D. L. (2007) Relation between Oral Reading Fluency and Reading Comprehension for Spanish-speaking Students Learning to Read in English and Spanish. Unpublished doctoral dissertation. University of Oregon, Oregon.

[8]. Baker, S., D. Simmons \& E. Kame'enui. (1997) Vocabulary acquisition: Research bases. In Simmons, D. C. \& Kame'enui, E. J. (Eds.) What reading research tells us about children with diverse learning needs: Bases and basics. Mahwah, NJ: Erlbaum.

[9]. Ball, E. (1993) Assessing phoneme awareness. Language, Speech, and Hearing Services in Schools, 24, 130-139.

[10]. Base, Graeme (1993) Animalia. Harry N. Abrams, New York, NY.

[11]. Bay Area Reading Task Force (1997) A reading-writing-language source book for the primary grades. San Francisco, CA: University School Support for Educational Reform.

[12]. Bear, D., L. Helman, S. Templeton, M. Invernizzi \& F. Johnston (2007) Words their way for English learners. Upper Saddle River, NJ: Prentice Hall.

[13]. Bear, D., M. Invernizzi, F. Johnston \& S. Templeton (2009) Letter and picture Sorts for emergent spellers (2nd edition) Upper Saddle River, NJ: Merrill/Prentice Hall.

[14]. Bear, D., M. Invernizzi, S. Templeton \& F. Johnston (2008) Words their way: Word study for phonics, spelling, and vocabulary instruction (4th edition) Upper Saddle River, NJ: Prentice Hall.

[15]. Bear, D.R., M. Invernizzi \& S. Templeton (1996) Words their way: Word study for phonics, vocabulary, and spelling instruction. Englewood Cliffs, NJ: Prentice Hall.

[16]. Bishop, A. \& S. Bishop (1996) Teaching Phonics, Phonemic Awareness, and Word Recognition. Teacher Created Materials, Inc.

[17]. Bradley, L. \& P. Bryant (1991) Phonological skills before and after learning to read. In S. A. Brady \& D. P. Shankweiler (Eds.), Phonological processes in literacy: A tribute to Isabelle Y Liberman (pp. 37-45). Hillsdale, NJ: Erlbaum.

[18]. Bradley, L. \& P. Bryant (1985) Rhyme and Reason in Reading and Spelling. Ann Arbor: University of Michigan Press.

[19]. Bravo-Valdivieso, L. (1995) A four year follow-up study of low socioeconomic status, Latin American children with reading difficulties. International Journal of Disability, Development and Education, (42) 189-202.

[20]. Burgess, J. \& Spencer, S. (2000) Phonology and pronunciation in integrated language teaching and teacher education. System 28, $191-215$.

[21]. Campbell, R. (2004) Phonics, naturally: Reading and writing for real purposes. Portsmouth, NH: Heinemann.

[22]. Carnine, D., J. Silbert \& E. Kameenui (1997) Direct instruction reading (3rd ed.). Upper Saddle River, NJ: Merrill/Prentice-Hall.

[23]. Carrillo, M. (1994) Development of phonological awareness and reading acquisition. A study in the Spanish language. Reading and Writing: An Interdisciplinary Journal (6) 279- 298.

[24]. Carter, A., Dillon, C. \& Pisoni, D. (2002) Imitation of nonwords by hearing impaired children with cochlear implants: Suprasegmental analyses. Clinical Linguistics and Phonetics 16, 619-638.

[25]. Catts, H. \& Vartiainen, T. (1993) Sounds Abound. Listening, Rhyming, and Reading. East Moline, IL: Lingui Systems Inc.

[26]. Chard, D. J. \& S. V. Dickson (1999) Intervention in School and Clinic. 34(5) 261-270.

[27]. Children's Educational Services, I. (1987) Test of Reading Fluency. Minneapolis, MN: Author.

[28]. Cisero, C. \& J. Royer (1995) The development and cross-language transfer of phonological awareness. Contemporary Educational Psychology, 20, 275-303.

[29]. Cohen, B.H. (1996) Explaining Psychological Statistics. Pacific Grove, CA: Brooks/Cole Publishing Company.

[30]. Costanza, P., Valentine, T. \& Baddeley, A. (1991) Phonological short-term memory and foreign-language vocabulary learning. Journal of Memory and Language 30, 331-347.

[31]. Davidson, R. \& J. Strucker (2002) Patterns of Word Recognition Errors Among Adult Basic Education Native and Nonnative Speakers of English. NCSALL Research Brief.

[32]. De la Colina, M., R. Parker, J. Hasbrouck \& R. Lara-Alecio (2001) Intensive intervention in reading fluency for at-risk beginning Spanish readers. Bilingual Research Journal, 25(4) 503-538.

[33]. Deno, S. \& L. Fuchs (1987) Developing curriculum-based measurement systems for data based special education problem solving. Focus on Exceptional Children, 19(8) 1-15.

[34]. Deno, S. \& P. Mirkin (1977) Data-based program modification: A manual. Reston, VA: Council for Exceptional Children.

[35]. Deno, S. L. (1985) Curriculum-based measurement: The emerging alternative. Exceptional Children, (52) $219-232$.

[36]. Denton, C., J. Hasbrouck, L. Weaver \& C. Riccio (2000) What do we know phonological awareness in Spanish? Reading Psychology (21) 335-352.

[37]. Derwing, T. \& Munro, M. (1997) Accent, intelligibility, and comprehensibility: Evidence from four L1s. Studies in Second Language Acquisition 20, 1-16.

[38]. Derwing, T. \& Rossiter, M. (2003) The effects of pronunciation instruction on the accuracy, fluency, and complexity of L2 accented speech. Applied Language Learning 13, 1-17.

[39]. Donnelly, K., S. Thomsen, L. Huber \& D. Schoemer, D. (1992) More than words: communication skill builders. Tucson, Arizona: Communication Skill Builders.

[40]. Doughty, C. \& Williams, J. (1998) Pedagogical choices in focus on form. In C. Doughty \& J. Williams (eds) Focus on Form in Classroom Second Language Acquisition (pp. 197-262). New York, NY: Cambridge University Press.

[41]. Durgunoglu, A., W. Nagy \& B. Hancin-Bhatt (1993) Cross-Language transfer of phonological awareness. Journal of Educational Psychology, 85, 453-465.

[42]. Eldredge, J. L. (2004) Phonics for teachers: Self-instruction, methods, and activities. Upper Saddle River, NJ: Pearson/Merrill Prentice Hall.

[43]. Fuchs, L. S, D. Fuchs, C. Hamlett, L. Walz \& G. Germann (1993) Formative evaluation of academic progress: How much growth can we expect? School Psychology Review, 22, 27-48.

[44]. Gardner, Beau (1994) Have You Ever Seen? : An ABC Book. New York : BGA Pub.

[45]. Gathercole, S.E. \& Baddeley, A. (1990) The role of phonological memory in vocabulary acquisition: study of young children learning new names. British Journal of Psychology 81, 439-454.

[46]. Gathercole, S.E., Willis,C. \& Emslie, H. (1994) The children's test of nonword repetition: A test of phonological working memory. Memory 2, 103-127.

[47]. George, D. \& Mallery, P. (2003) SPSS for Windows Step by Step: A Simple Guide and Reference. 11.0 Update (4th edn). Boston, MA: Allyn \& Bacon.

[48]. Goldsworthy, C. (1996) Developmental reading disabilities: A language-based reading approach. San Diego, CA: Singular Publishing Group, Inc.. 
[49]. Good, R. \& G. Jefferson (1998) Contemporary perspectives on Curriculum-Based Measurement validity. In M. R. Shinn (Ed.), Advanced applications of Curriculum-Based Measurement (pp. 61-88) New York: Guilford.

[50]. Good, R., R. Kaminski, M. Shinn, J. Bratten, L. Laimon, S. Smith \& N. Flindt, N. (2004) Technical Adequacy and Decision Making Utility of DIBELS (Technical Report No. 7). Eugene, OR: University of Oregon.

[51]. Grover, M. (1996) The Accidental Zucchini: An Unexpected Alphabet, Harcourt School Publishers

[52]. Hart, B. \& R. Risley (1995) Meaningful differences in the everyday experience of young American children. Baltimore: Paul H. Brookes.

[53]. Hasbrouck (1998) Reading fluency: Principles for instruction and progress monitoring. Professional Development Guide. Austin, TX: Texas Center for Reading and Language Arts, University of Texas at Austin.

[54]. Hasbrouck, J. \& G. Tindal (1992, Spring) Curriculum-based oral reading fluency norms for students in grades 2 through 5. Teaching Exceptional Children, pp. 41-44.

[55]. Heilman, A. W. (2002) Phonics in proper perspective. Upper Saddle River, NJ: Merrill Prentice Hall.

[56]. Hempenstall, K. (2002) Phonological processing and phonics: Towards an understanding of their relationship to each other and to reading development. Australian Journal of Learning Disabilities. 7(1) 4-29.

[57]. Hempenstall, K. (2007) Literacy research: The Australian and international context. Refereed paper presented in symposium: "Changing times - the recent Literacy revolution in Australia: Policy changes, political implications, and the new literacy agenda for schools". Australian Association for Research in Education Conference Engaging Pedagogies, Adelaide 27th - 30th November, 2006.

[58]. Holt, G. M. (1995) Teaching Low-Level Adult ESL Learners. ERIC Digest: Adjunct Eric Clearinghouse for ESL Literacy Education, Washington D. C.

[59]. Invernizzi, M., J. Meir \& C. Juel (2007) PALS 1-3: Phonological awareness literacy screening 1-3 (6th ed). Charlottesville, VA: University Printing Services.

[60]. Invernizzi, M., F. Johnston \& D. Bear (2009) Word sorts for within word pattern spellers (2nd edition). Boston, MA: Allyn \& Bacon/Pearson.

[61]. Invernizzi, M., L. Swank \& C. Juel (2007) PALS-K: Phonological Awareness Literacy Screening-Kindergarten (6th edition). Charlottesville: University Printing Services.

[62]. Jager-Adams, M. (1997) Phonemic Awareness in Young Children: A Classroom Curriculum. Paul H. Brookes Publishing Company

[63]. Jiménez, J. \& M. Ortiz (2000) Metalinguistic awareness and reading acquisition in the Spanish language. The Spanish Journal of Psychology, 3(1) 36-46.

[64]. Johnston, F., M. Invernizzi \& D. Bear (2009) Word sorts for syllables and affixes spellers (2nd edition). Boston, MA: Allyn \& Bacon/Pearson.

[65]. Johnston, F., M. Invernizzi, C. Juel \& D. Lewis-Wagner (2009) Book buddies: A tutoring framework for struggling readers (2nd edition). New York: The Guilford Press

[66]. Johnston, F., M. Invernizzi, D. Bear \& S. Templeton (2009) Word sorts for letter name-alphabetic spelling (2nd edition). Boston, MA: Allyn \& Bacon/Pearson.

[67]. Jones, M. L. (1996) Phonics in ESL Literacy Instruction: Functional or Not? Paper from the proceedings of the World Conference on Literacy, Philadelphia, March 1996.

[68]. Juel, C. (1988) Learning to read and write: A longitudinal study of 54 children from first through fourth grades. Journal of Educational Psychology (80) 437-447.

[69]. Kenworthy, J. (1987) Teaching English pronunciation. London: Longman.

[70]. Kaminski, R. A. \& R. H. Good (1996) Toward a technology for assessing basic early literacy skills. School Psychology Review (25) 215-227.

[71]. Kaminski, R. A. \& R. H. Good (1998) Assessing early literacy skills in a problem solving model: Dynamic Indicators of Basic Early Literacy Skills. In M. R. Shinn (Ed.), Advanced applications of Curriculum-Based Measurement (pp. 113-142). New York: Guilford.

[72]. Kaminski, R., K. D. Cummings, K. A. Powell-Smith \& R. H. Good (2008) Best practices in using Dynamic Indicators of Basic Early Literacy Skills for formative assessment and evaluation. In A. Thomas and J. Grimes (eds.) Best practices in school psychology V. Bethesda, MD: National Association of School Psychologists.

[73]. Kozol, J. (2001) Savage inequalities : children in America's schools. New York: Crown Pub.

[74]. Krashen, S. (1981) Second Language Acquisition and Second Language Learning. Oxford: Oxford University Press.

[75]. Krashen, S. (1982) Principles and Practice in Second Language Acquisition. New York: Pergamon Press.

[76]. Krashen, S. (1994) The input hypothesis and its rivals. In N. Ellis (ed.) Implicit and Explicit Learning of Languages (pp. 45-77). London: Academic Press.

[77]. Laimon, D. E. (1994) The effects of a home-based and center-based intervention on atrisk preschool children's early literacy skills. Unpublished Doctoral Dissertation, University of Oregon, Eugene.

[78]. Learning First Alliance (1998) Every child reading: An action plan of the Learning First Alliance. American Educator (1-2) 52-63.

[79]. Liberman, I. Y., D. Shankweiler, F. W. Fischer \& B. J. Carter (1974) Explicit syllable and phoneme segmentation in the young child. Journal of Experimental Child Psychology (18) 201-212.

[80]. Lightbown, P. (2000) Classroom SLA research and second language acquisition. Applied Linguistics 21, 431-462.

[81]. Long, M. \& Robinson, P. (1998) Focus on form: Theory, research and practice. In C. Doughty and J. Williams (eds) Focus on Form in Classroom Second Language Acquisition(pp. 15-41). New York: Cambridge University Press.

[82]. Lyon, G. R. (2002) "Learning Disabilities and Early Intervention Strategies: How to Reform the Special Education Referral and Identification Process," Hearing before the Subcommittee on Education Reform Committee on Education and the Workforce United States House of Representatives. archives.republicans.edlabor.house.gov/.../idea6602/lyon.htm

[83]. Marston, D. \& D. Magnusson (1988) Curriculum-based measurement: District level implementation. In J. Graden, J. Zins \& M. Curtis (Eds.), Alternative educational delivery systems: Enhancing instructional options for all students (pp. 137-172). Washington, DC: National Association of School Psychology.

[84]. McBride-Chung, C. \& R. Kail (2002) Cross-cultural similarities in the predictors of reading acquisition. Child Development, 73 (5) 1392-1407.

[85]. McCracken, R. A.\&M. J. McCracken (1986) Stories, Songs and Poetry to Teach Reading and Writing, Teachers College Press.

[86]. Merriam, E. \& D. De Groat (1992) Where Is Everybody?: An Animal Alphabet. New York: Simon \& Schuster

[87]. Moats, L. C. (1999) Teaching reading is rocket science: What expert teachers of reading should know and be able to do. Washington, D. C.: American Federation of Teachers. 
[88]. Munro, M.J. \& Derwing, T.M. (1995) Foreign accent, comprehensibility and intelligibility in the speech of second language learners. Language Learning 45, 73-97.

[89]. Murphy, J. (1997) Phonology courses offered by MATESOL programs in the US. TESOL Quarterly 31, $741-764$.

[90]. National Reading Panel (2000) Teaching children to read: An evidence-based assessment of the scientific research literature on reading and its implications for reading instruction [on-line]. Available: http://www.nichd.nih.gov/publications/nrp/report.cfm.

[91]. National Research Council (1998) Preventing reading difficulties in young children. Washington, DC: National Academy Press.

[92]. Nelson, M. (2003) Assessing the early literacy skills of young English learners: Use of DIBELS in Spanish. Unpublished doctoral dissertation, University of Oregon, Eugene.

[93]. Nunnaly, J. (1978) Psychometric Theory. New York: McGraw-Hill.

[94]. Piske, T., MacKay, I. \& Flege, J. (2001) Factors affecting degree of foreign accent in an L2: A review. Journal of Phonetics 29, $191-215$.

[95]. Robinson, P. (2005) Aptitude and second language acquisition. Annual Review of Applied Linguistics 25, 46-73.

[96]. Rayner, K. \& Pollatsek, A. (1989) The psychology of reading. Englewood Cliffs, NJ: Prentice Hall

[97]. Rhymes and Fingerplays mrsjonesroom.com/songs/alphlist.html, p. 21 "Good Listeners"

[98]. Richards, J. C., J. Platt \& H. Platt (1992) Longman dictionary of language teaching and applied linguistics. London: Longman.

[99]. Salvia, J. \& J. E. Ysseldyke (2001) Assessment ( $8^{\text {th }}$ ed.). Boston: Houghton Mifflin.

[100]. Schmidt, R. \& Frota, S. (1986) Developing basic conversational ability in a second language: A case study of an adult learner of Portuguese. In R. Day (ed.) Talking to Learn: Conversation in Second Language Learning (pp. 237-326). Rowley, MA: Newbury House.

[101]. Schmidt, R. (1990) The role of consciousness in second language learning. Applied Linguistics 11, $129-158$.

[102]. Schmidt, R. (1995) Consciousness and foreign language learning: A tutorial on the role of attention and awareness in learning. In R. Schmidt (ed.) Attention and Awareness in Foreign Language Learning (Tech. Rep. No. 9, pp. 1-63). University of Hawaii at Manoa, Second Language Teaching and Curriculum Center.

[103]. Shaywitz. S. (2003) Overcoming dyslexia: A new and complete science-based program for reading problems at any level. New York: Knopf.

[104]. Shinn, M. R. (Ed.) (1989) Curriculum-based measurement: Assessing special children. New York: Guilford.

[105]. Signorini, A. (1997) Word reading in Spanish: A comparison between skilled and less skilled beginning readers. Applied Psycholinguistics (18) 319-344.

[106]. Songs, Poems, Chants and Rhymes http://www.jmeacham ... The Teacher's Guide Children's Songs http://www.theteachersguide.com/ChildrensSongs.htm

[107]. Stanovich, K. E. (1986) Matthew effects in reading: Some consequences of individual differences in the acquisition of literacy. Reading Research Quarterly (21) 360-406.

[108]. Stanovich, K. E. (1999) The Sociopsychometrics of Learning Disabilities. Journal of Learning Disabilities, 32(4) 350-361.

[109]. Strickland, P. (1993) Auditory Processes, Revised Edition, Academic Therapy Publication.

[110]. Swank, L. (1991) A two-level hypothesis of phonological awareness (Doctoral dissertation, University of Kansas). Dissertations Abstracts International, 53-08A(2754).

[111]. Swank, L. (1997) Linguistic influences on the emergence of written word decoding in first grade. American Journal of SpeechLanguage Pathology (6) 62-66.

[112]. Templeton, S., F. Johnston, D. R. Bear \& M. Invernizzi (2009) Vocabulary Their Way. Boston, MA: Allyn \& Bacon.

[113]. Templeton, S., F. Johnston, D. R. Bear \& M. Invernizzi (2009) Word Sorts for Derivational Spellers (2nd edition). Boston, MA: Allyn \& Bacon/Pearson.

[114]. Tindal, G., D. Marston \& S. Deno (1983) The reliability of direct and repeated measurement (Research Rep. 109). Minneapolis, MN: University of Minnesota Institute for Research on Learning Disabilities.

[115]. Vaughn, S., P. Mathes, S. Linan-Thompson \& D. Francis (2005) Teaching English language learners at risk for reading disabilities to read: Putting research into practice. Journal of Learning Disabilities Research and Practice, 20(1) 58-67.

[116]. Warrick, N., H. Rubin \& S. Rowe-Walsh (1993) Phoneme awareness in language-delayed children: Comparative studies and intervention. Annals of Dyslexia (43) 153-173.

[117]. Watson, J. (2004) Examining the reliability and validity of the Indicadores Dinámicos del Exito en la Lectura (IDEL): A research study. Unpublished doctoral dissertation, University of Oregon.

[118]. Yopp, H. K. (1992) Developing Phonemic Awareness in Young Children. Reading Teacher (45:9) 696-703.

[119]. Yopp, H. \& L. Stapleton (2008) Conciencia Fonémica en Español (Phonemic Awareness in Spanish). The Reading Teacher 61(5) 374-382.

[120]. Yopp, H., R. Yopp \& H. Taylor (1991) The Teacher Track Project: Increasing teacher diversity. Action in Teacher Education, 13(2) $36-42$. 